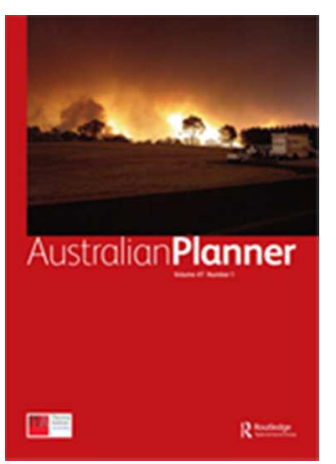

\title{
Gerotopia: Producing lifestyle communities for baby
} boomers

\begin{tabular}{|r|l|}
\hline Journal: & Australian Planner \\
\hline Manuscript ID: & RAPL-2012-0046.R2 \\
\hline Manuscript Type: & Peer reviewed Article \\
\hline Keywords: & boomers, active adult lifestyle communities, commodity \\
\hline \multicolumn{2}{|l}{} \\
\hline
\end{tabular}

SCHOLARONE ${ }^{\text {Ix }}$

Manuscripts 
Gerotopia: Producing lifestyle communities for baby boomers

\begin{abstract}
Australia's ageing population will have a critical impact on the economy, the health care service and housing provision. Active Adult Lifestyle Communities (AALCs) have recently emerged on the Australian housing market in response to many boomers' calls for housing choice as they embark upon the 'retirement' phase of life. The lifestyle contract in these developments means government intervention and support is minimised as residents take the necessary steps to secure their own health and well-being. This paper focuses on the commodification of 'lifestyle' in master planned communities (MPCs) and AALCs in particular. I argue that AALCs offer and largely deliver a lifestyle that addresses the needs, requirements and desires for mental and physical health and well-being of residents/boomers. The proliferation of such developments in the residential landscape has implications, some of which this paper will highlight. The literature identifies a need for further research into housing needs, choices and preferences of baby boomers, as a unique and influential cohort, as they enter retirement and this paper addresses this need.
\end{abstract}

KEYWORDS: boomers, Active Adult Lifestyle Communities, commodity

\title{
Introduction
}

The characteristics frequently ascribed to many boomers (b.1946-1965): lifestyle focused, skilled consumer, financially conservative, politically aware etc., reflect the social and political contexts of their time and place. Unsurprisingly these characteristics have influenced the transformations in many housing landscapes, in particular the ones that boomers have built, inhabited and prospered in throughout their working careers. It is also these characteristics that are currently driving another transformation in housing landscapes, the 
Active Adult Lifestyle Community (AALC), as many boomers enter into the retirement phase of their lives.

AALCs are a sub-species of the master planned community (MPC), they are age segregated residential developments designed specifically for active adults between the ages of 50-74 (see Suchman, 2001; Schwarz, 2009). They are usually niche market developments, targeted at the cashed-up, financially secure, healthy and active baby boomer cohorts. AALCs 'provide an alternative perspective on the notion of ageing in place ... [and] are intended to be dynamic environments, advocating independent living and a good quality of life. In so doing, they have become a serious business...' (Grant 2006 p. 103). Moving into an AALC for some boomers is about 'making a transition to a new life ... bypassing and resisting the negative expectations and stereotypes of what growing older is supposedly about' (Grant 2006 p. 102). AALCs have been a feature in the USA landscape since the 1950s and this phenomenon has grown in recent years, in particular in the state of Florida, resulting in notable impacts and implications (see Fishman 2010).

AALCs began to emerge in the Australian and New Zealand (see Grant 2006, 2007) landscapes in the early 2000. These versions of the American model reflect the local cultural, political and economic patterns of the countries in which they are built. The tenure of AALCs varies but most include a combination of leasehold and ownership with no associated entry and exit fees. In Queensland, the Manufactured Homes Act 2003 governs the tenure of most AALCs. This Act operates on a two-tiered basis that gives ownership of the house to the buyer who then leases the site where the house stands. This means that the land the house occupies is on a perpetual leasehold basis and the security of the tenure is protected under the Act. The house owner is free to sell the house at anytime without attracting exit fees, which are common to traditional retirement village models. My definition of an AALC draws upon 
some of the elements that characterised the early 1970s Australian retirement villages and responds to McGovern and Baltins (2002) Australian typology of retirement villages, Resort Style as summarised in table 1.

[insert Table 1 around here]

Table 1: Characteristics of an AALC

This paper examines some of the lifestyle discourses in AALCs as a subset of the MPC project. It has been argued (Bosman 2005) that the massification and commodification of 'lifestyle' emerged as a governmental rationality in the MPCs of the 1980s within the spaces of neoliberalism. Current research and marketing data, as demonstrated in this paper, suggest that the lifestyle sold in AALCs acts as a technique of self-government (Foucault 1997). The lifestyle requires residents to take responsibility for and be active in the government of their own health and well-being. And correlated with this, residents will be active in the government of the health and well-being of the community and the population. AALCs then have direct benefits to the self, the community and society as outlined in this paper. Initial research and market indicators show that AALCs address the desires, needs and requirements of residents/boomers as they age. The paper also highlights some of the implications of AALCs in the residential landscape.

A desktop analysis investigated the emergence and impact of AALCs in three sites: Australian, New Zealand and the USA, to ensure data collection had international relevance. These locations were chosen because of similarities between socio-economic, ideological and physical housing landscapes. All three countries have high levels of house ownership, the suburban landscape is characterised by single family detached dwellings and gated communities are a growing phenomena. I acknowledge that these characteristics are not 
exclusive, nor are AALCs unique to these countries alone. In choosing the investigation sites I opted for those sites that were familiar and where data was readily available. The analysis does not distinguish between Australia, New Zealand and USA data but rather draws upon common ground and in so doing relates a single narrative. Where applicable USA and Australian data is highlighted to emphasise a particular point. In the Australian context the paper looks specifically at AALCs on the Gold Coast in Southeast Queensland (SEQ).

The first section of this paper briefly looks at some of the, by now, well documented characteristics of boomers, as current and potential residents/consumers of AALCs. Drawing upon some of the boomer preferences (however problematic) the following section discusses the commodification of 'lifestyle' in AALCs and MPCs. The marketed lifestyle largely relates to the social and physical characteristics of the development. Discussion then leads into the physical, social and mental health and well-being benefits to residents living in AALCs. This section also looks at some of the possible and actual impacts that these developments have. Research limitations and the potential for further research are outlined at the end of the paper.

\section{Boomers}

As elsewhere in the world, baby boomers constitute a significant percentage of the Australian population and many are reported to have high average annuity, moderate debt and high levels of house ownership, with four out of five Australian boomers being paid-up house owners (Kendig \& Neutze 1999; Harding \& Kelly 2007; Suchman 2001; Grant 2006). Boomers are also said to perceive themselves as being much younger than they actually are and this somewhat misleading perception then influences their choice of lifestyle, house design and retirement location (Kirk 2008). The first wave of baby boomers are in their mid 
60s and a popular opinion is that 'there's no indication they'll slow down. Instead, their young-minded demands and massive buying power will continue to influence the housing industry' (Binsacca, 2006). While this may not be the case for all boomers, many are noted for being experienced and discerning, 'black-belt', consumers who typically spend more on leisure and recreation than their younger cohorts (Magwood n.d.; Isleib \& Brady 2010; Harding \& Kelly 2007). There is an important caveat to make here. It is an oversight to think that all baby boomers are alike and have the same capacity to be active consumers. Boomers are as diverse as any other Australian cohort and many will not fit the given characteristics. The generalisations made in this paper are not indented to stifle individuality and diversity of people born within the stated 20 year period. The characteristics given here are commonly cited in academic, marketing and real estate literature and are therefore relevant to this context, as the target market for AALCs.

The housing industry is implicated in a number of ways by the ageing population and boomers in particularly. Pre the global financial crisis property headlines (Ray White Property News 2009; Gold Coast Publications 2009) heralded 'Baby boomers taking over Gold Coast real estate' and 'A boom town for boomers'. This trend was supported by local real estate analysts and two Gold Coast City Council publications: 'A Social Profile of Older People in Gold Coast City', 2007 and 'Plan for an Aging Community 2008-2010', 2008. Although the Gold Coast housing market is currently (2012) experiencing a low, some property analysts are predicting a 'surge in sale rates' (Ardern 2012, UDIA 2012) bolstered by the continued appeal of the Gold Coast as a retirement location for boomers. According to Nevill (2012) retirement housing constitutes 5.3 per cent of the housing market. This is forecast to grow as the boomer 'bulge' moves into the retirement life-stage adding, on average, another 5000 retirement houses per year. 
Of particular interest here, is the influence that baby boomers' lifestyle preferences will have on housing landscapes as they enter retirement. Although initial reports suggest that the majority of boomers show a preference to age in place (KPMG 2009; Beer et al 2009; Smith 2009) many also indicate their intention to move to a more convivial and desirable location compatible with their lifestyle aspirations. This is backed by research which indicates that many boomers express a strong desire for a 'seachange' and to downsize their family home and upsize their lifestyle (Myers \& Ryu 2008; Harding \& Kelly 2007; AXA 2006, 2008; Binsacca 2006). Research also confirms that many boomers are purchasing a lifestyle, the good life, rather than just a house. Importantly this lifestyle purchase is influenced by particular images of a specific type of place and community, one that typifies the purchase's needs, aspirations and interests (Suchman 2001). The commodification of lifestyle is not new nor is it unique to AALCs. It was in the advent of the MPC that a particular lifestyle was marketed as a means to differentiate those who 'belonged' and those who did not (Bosman 2005). MPCs and by association AALCs tell us something about how suburban identities were constituted in the late 20 th and early 21 st century.

\section{The commodification of 'lifestyle'}

The planning processes and practices intrinsic to the making of AALCs are similar in many respects to those of MPCs (Knox 1992; Minnery \& Bajracharya 1999; Costley 2006; Bartling 2008; Cheshire et al 2009). MPCs of the 1980s differed from earlier versions of the same partly because of the neoliberal politics of the day (Bosman 2009). MPCs are profit orientated and economically driven more so than previous planned residential developments, for example Colonel Light Gardens (Garnaut 1999). At the large scale they are perceived as strategic planning ventures that economically and efficiently deliver 'homes' for 'people'. 
During the 1980s these developments represented 'a new kind of element in the built environment: thoroughly marketed, closely negotiated and carefully packaged (Knox 1992).' It was in and through these housing landscapes that aspirations for a particular lifestyle began to 'take precedence over the role of the [house] as anchor of personal identity' (Murray 2007 p. 95-8). In this respect, MPCs can be seen as a 'tangible expression of social attitudes and beliefs' (Fletcher 2010 p. 460, see also Boseman 2007) of a particular place and in a specific time.

The imaginary embedded in the lifestyle rhetoric of many of the MPCs of the 80s and 90s was heightened by the political, social and economic context of the time: the flourishing of neoliberal thinking, the oil crisis, impacts of globalisation, population growth, introduction of new technologies etc (Bosman 2009). It was also a rejoinder to much of the anti-suburban sentiment, where suburbia was 'often characterised by monotonous planning and dreary architecture' (Tract (S.A.) 1976 p. 2). Stretton's (1989 p. 10) anti-suburban description of a 1980s imagining of Australian suburban life is classic: 'dreary dormitories where life shrivels, festers, taps its foot in family prisons. All relations oppress; ... conversations, if any are boring; neighbours pry.' Significantly there was growing concern about the 'loss of community' in the early 80s (Bosman 2005). The 'village' planning practices that were to comprise the MPC lifestyle ostensibly addressed much of the negative suburban rhetoric including the 'loss of community'. The perceived need for community relationships within MPCs was often the outcome of intensive and selective market research which suggested that many homebuyers were looking for 'a way to put small-town neighbourliness back into their lives (Martin 1996).' 
The physical planning of a MPC lifestyle is typically economically driven with little opportunity for incremental development outside of the planned staged release, sale and development of land. Covenants limit personalised interventions and ensure a degree of sameness to streetscapes. House prices and targeted marking also produce a relatively uniform residential profile. It is common for developers to market MPCs to a niche market, determined by particular lifestyles within a life-stage. These theme 'communities' range from the active to the passive. Travel within the development is designed primarily for the motor vehicle with limited pedestrian circulation. Residents mostly buy into the development for the particular facilities and lifestyles that are on offer.

The planning of MPCs to ostensibly offer a specific lifestyle, often means the provision of 'lifestyle' amenities are privileged over environmental concerns like peak oil, solar orientation, rain water collection, topography, local climate, native vegetation etc. The provision (or not) of golf courses, club houses, swimming pools and spas, tennis courts, recreational green spaces (with or without infrastructure), hike and bike trails and 'low maintenance' subdivisions and landscaping are all marketed as a 'lifestyle choice' rather than being provided as necessities for everyday life. 'Lifestyle' is produced by the provision of things and the experience of these things. The effects these things have on the landscape and non-human subjects are often not part of the planning process. The long term sustainability of the lifestyle that many MPC residents bought into is uncertain given current concerns of climate change, peak oil and fiscal crises. Like most commodities, the MPC lifestyle on sale may have a use by date. This has not however affected marketing strategies or consumer demand for specific lifestyle communities.

\section{The AALC 'lifestyle'}


The most recent variation of the MPC is the AALC. This mutation (in Australia) is on a smaller scale than most MPCs but the preoccupation with 'lifestyle' and in particular ideals of community in the planning and development of these landscapes has not decreased. This is problematic because the planning techniques and practices that constitute these developments produced identities and set up hierarchical relationships between collectives (groups or individuals), based upon normative and 'naturalised' values relating to 'the good life' (Bosman 2012). As a consequence, the suburban landscape largely reflects certain lifestyles and subjectivities, and alienates, limits or denies others.

Buchli (2010 p. 511) suggests that 'The home as site of lifestyle pursuit in its seemingly banal nature is part of the neo-liberal contract with state power by which self-governing subjects are constituted.' This is demonstrated in AALCs where the lifestyle has been specifically designed to appeal to the growing retiring boomer cohort. In these developments residents are required to manage personal and community risks attached to ageing: mental and physical health and well being, social engagement and neighbourly support. The lifestyle contract means government intervention and support is minimised as residents take the necessary steps to secure their own health and well being. Research tells us (Waldegrave 2012) that house ownership and independence contribute significantly to quality of life, which contributes to health and well being, which in turn contributes to the fiscal position of the public health system. The more responsibility individuals take to manage risks attached to mental and physical health and well being, social engagement and neighbourly support; the less responsibility lies with the government. The problem of course is with the 'deviant' cohorts'; those who choose or are not able to, for whatever reason, take up the role of the 'self-governing subject'. 


\begin{abstract}
AALCs and the good life
Matusik (2011) reports that 35 per cent of the over 55 household cohort moves house 'primarily for lifestyle reasons', and that this group of people place 'a high value on living with others of similar background, age and interests'. Given this it is not surprising that a rough internet and local newspaper tally (villages.com.au, realestate.com.au and The Sun) identified approximately 30 AALCs in SEQ. The number of houses within these developments ranges from the low 100 s to the mid 500s. The popularity of AALCs lies partly in 'their relative ability to tap into the imaginative potential of community and place, to create a secure and convincing narrative for identity in late life' (Biggs et al. 2000 p. 653). AALCs possibly afford opportunities for residents to re-create meaning and purpose in their life.
\end{abstract}

The planning of most AALCs ostensibly follows new urbanist principles: interconnected subdivision layout, attention to streetscape and the pedestrian and or golf cart experience and the inclusion of accessible community infrastructure (clubhouse and or a community centre usually designed to include a 'village square' of some kind). These features are also central to much of the age friendly cities literature (WHO 2007). Way-finding and walkability are key to residential landscapes that foster independence and good physical health in old age. Similarly the provision of clubhouses and communal spaces provide opportunities for residents to socialise and build bonds of community and develop feelings of belonging, all of which are essential to mental well-being (WHO 2002). Importantly, houses in AALCs can be designed to accommodate the needs and requirements of residents as they age and or become less mobile. A proponent of an AALC on the Gold Coast (unknown 2009 p. 31) writes that 'Active lifestyles, both physical and mental are encouraged by the physical design elements of [the AALC] and also through the facilitation of management ....' The physical design of most AALCs is consistent with best practice principals identified by key bodies (WHO 
2007). Preliminary research, as this paper suggests below, indicates that many AALC residents are actively engaged in techniques of self-government with the aim to secure their own health and well-being.

In SEQ most AALCs (as with MPCs) are located in areas that are car reliant and poorly serviced by public transport. This is partly because AALCs require large development sites to accommodate the required recreational facilities: clubhouses, bowling greens, tennis courts etc. and detached houses. Nevill (2012) highlights the issues around location of and access to community infrastructure required for retirement developments generally. He reports that the availability of suitable land close to existing services and facilities is scarce and the property market is very competitive, particularly given the financial returns on high-rise apartment developments. Given this situation, some members of the retirement sector are calling for government intervention to provide 'more explicit retirement zoning' closer to suburban centres (Nevill 2012). This call is problematic for large scale developments like AALCs given the existing segmented ownership patterns of much of these 'inner suburban' parcels of land.

Because many AALCs occur on greenfield sites there are opportunities for subdivision design and house siting to follow environmental considerations, particularly with regard to solar access and rainwater collection. While these practices have not been wide spread to date they are beginning to have some traction (see Seachange). The planting of native vegetation and the provision of communal vegetable gardens also supports sustainable living agendas, however marginal. Although most AALCs are detached suburban 2-3 bedroomed houses there are opportunities to develop more environmentally sustainable residential models. In the Gold Coast there are currently two AALC high-rise buildings offering all the facilities and 
amenities of the suburban models. These residential towers also provide care facilities and 24/7 emergency call appliances in every apartment. The importance here is not just in producing an environmentally sustainable residential environment but rather in the quality of life that these residential environments afford.

The planning processes and practices intrinsic to the making of AALCs are similar in many respects to those of MPCs (Knox 1992; Minnery \& Bajracharya 1999; Costley 2006; Bartling 2008; Walters \& Rosenblatt 2008; Cheshire et al. 2009). The major difference is that AALCs are age restricted, the majority of residents are retired and residents have similar socioeconomic characteristics. MPCs of the 80 s and 90 s commonly catered for first homebuyers, investors, renters, young couples and young families, within a targeted market cohort and particular economic bracket. This expanded over the years to include second and third homebuyers and a sprinkling of empty nesters. Although many MPCs did not specifically include social housing, they did nonetheless cater for a reasonable range of housing products at different prices albeit within a specified price bracket. In AALCs the picture is very different.

Resident age restrictions are enforced by property Title Deed and covenants, and children are prohibited from residing in the community for any length of time. There are no investors or renters in AALCs resulting in a socio-economic and demographic composition that McHugh and Larson-Keagy (2005) describe as 'birds of a feather'. Suchman (2001 p.74-5) explains:

They want to live among their peers: people of similar socioeconomic backgrounds who have shared some of the same life experiences, think the way they do, and are at a stage when they have the time and inclination to enjoy their lives. An [AALC] also offers a club like atmosphere that not only "includes us" 
but "excludes them." Part of the appeal of an [AALC] is that it is a controlled environment, where the way of life is safe, consistent, predictable, comfortable, and less rushed and stressful than life in the larger, workaday world.

The planning and marketing of community, the provision of which is frequently cited (Grant 2006; Walters \& Rosenblatt 2008) by planners and developers as being essential to achieving the health and well-being of individuals, is at the core AALCs and it encapsulates the lifestyle on offer. Most literature confirms that bonds of community are more commonly created between people of similar age, income, values, background and experiences (see Alperson 2002; Rosenblatt et al 2009; Panelli \& Welch 2005). It seems that AALCs are the stuff that community relations are made of. This sentiment is supported by AALC testimonials (Seachange; Halcyon; The Villages). The purported realisation of a healthy, active and socially engaged lifestyle, supported by the continued consumer demand for this type of residential landscape, suggests that the number of AALC developments will continue to increase. This will pose a number of challenges including but not limited to: the provision of similar housing models for those who cannot afford to buy into the lifestyle as it is produced by an AALC and; to provide a lifestyle that embeds environmental and climate change concerns.

A significant factor in the reported health and well-being of AALC residents can be attributed to house ownership. House ownership has a strong correlation with quality of life and wellbeing (Waldegrave 2012). Research finds that the health and well-being of AALC residents improves significantly within the first year of residency (see Grant 2007; Bowling 2009) and residents indicate high levels of lifestyle satisfaction (Beer et al 2009; Unknown 2009; Interview with a Villager 2011 a, b, c). In an article (unknown 2009 p. 31) about a Gold 
Coast AALC it is reported that 73 per cent of residents surveyed indicated that their life had significantly improved since becoming house owners within the development with 50 per cent reporting that their overall well-being had also improved. The improvement in health and well-being of AALC residents can be attributed to the physical and social planning of AALCs and also to the lack of housing risks associated with aging in place; principally fear of isolation, crime and risks attached to property (as opposed to house) ownership.

It is often the appeal of remaining independent and active that attracts many boomers to move into an AALC. It is also this appeal that makes these developments attractive to government agencies and developers. Active and independent (and therefore healthy) residents can equate to economic benefits. Suchman (2001: 21) argues that 'active adults impose less of a burden on most public services than do residents of other types of developments'. This is because residents of AALCs are (required to be) healthy and most public services are offered privately within the confines of the gates. Also because of the nature of the development and stable tenure of the residents fire and police services are seldom required (Schwarz, 2009). Importantly the development of AALCs has been seen as a means to broaden the tax base and increase the GDP of a local area, through benefits gained from services providers rather than from real estate and housing markets (Brodnitzki, 2007).

On another tack, many coastal cities are attracting a significant number of retirees and conflicts between tourism activities and retirement residential landscapes are inevitable. Retirees are less likely to benefit from economic outcomes of tourists and tourism activities because they are not necessarily seeking employment and because they tend not to participate in tourism activities. Also, when tourism is a major component of the GDP most policies and funding will focus on advancing and supporting the industry rather than on the provision of 
services to address the needs of a particular cohort. This suggests, as others have done, that the development of AALCs, as a privatised and semi self-sufficient model, offers a viable solution to housing the growing retiree population (Blechman 2008). A solution that is not only good for business but is also beneficial to the health and well-being of the residents. This solution however may not address issues of social polarisation, inequity and intergenerational social responsibilities. Nonetheless the continued development and relative success of AALCs suggest that they can be read as 'a tangible expression of social attitudes and beliefs' (Fletcher 2010 pp. 460) of some boomers and an indication of future prospects.

\section{Conclusion}

MPC were largely planned and developed by boomers in accordance with their principles, aspirations and contextual environments. Although these developments were lifestyle orientated they were car dependant and not designed to accommodate the needs and requirements of their makers as they aged. With the beginning of the new millennium a new kind of housing landscaping is emerging on the market, the AALC. The marketed lifestyle is familiar to many boomers and in keeping with the now well recognised characteristics of the boomer cohorts, as outlined at the beginning of this paper.

Many of the residential landscapes produced by and for boomers, in particular the MPCs of the 1980s-90s and the AALCs of the 2000s, continue to shape and mould (for better or worse) the everyday experiences of current and future generations. The number of AALCs in SEQ, while not currently statistically significant, could grow to become a major feature of the residential landscape in much the same way that MPCs have, over the last three decades, become a dominant characteristic of suburbia. AALCs impact residential landscapes in a 
number of ways, especially in relation to built form, social relations and economic trends. At the same time AALCs open up significant opportunities for future residential development.

My particular concern has been with the commodification of lifestyle and some of the impacts, implications and opportunities that AALCs are producing. Academic research into AALCs is beginning to have traction in Australia at undergraduate and postgraduate levels. The potential for both qualitative and quantitative research in this area is equal to that produced by previous studies into MPCs. Opportunities for further research include an analysis of the fiscal benefits of AALC residents to the national and state aged care sector and a comparative analysis between AALCs and current retirement village models. Further research is needed into the conditions which will enable local governments to produce growth management strategies that ensure housing equity in the provision of retirement housing. Importantly, as boomers continue to enter the retirement phase of their life over the next two decades, there is a need for ongoing investigation and monitoring of their housing expectations, needs and requirements. Important research questions will need to ask about the relationship of AALCs and the nature of growing old and about the social, financial and physical impacts of developing segregated residential enclaves.

\section{Acknowledgements}

My thanks to the two anonymous referees for their support of this research and their helpful and constructive comments on earlier versions on this paper.

\section{References}

Alperson, P. (ed.) 2002. Diversity \& Community: An Interdisciplinary Reader. Malden: Blackwell.

Ardern, L. 2012 Coast Property Market Back on Boil, [Online] Available: http://www.goldcoast.com.au/article/2012/03/23/401631_gold-coast-real-estate.html [Accessed on 27 March 2012]. 
AXA 2008. Australia tops the world for retirement - Study shows... News Release [Online]. Available: http://www.axa.com.au/axa/axa.nsf [Accessed May 2010].

AXA 2006. Retired life in the lucky country - new study reveals Australian retirees among happiest in the world. News Release [Online] Available: http://www.axa.com.au/axa/axa.nsf [Accessed May 2010].

Bartling, H. 2008. A master-planned community as heterotopia: The Villages, Florida. In M. Dehaene, \& L. Decauter, (eds.) Heterotopia and the City: Public Space in a Postcivil Society. Abingdon: Routledge.

Beer, A., Faulkner, D., Baker, E., Tually, S., Raftery, P. \& Cutler, C. 2009. Our Homes, Our Communities: The aspirations and expectations of older people in South Australia. Adelaide: Flinders University.

Biggs, S., Bernard, M., Nettleton, H. 2000. Lifestyles of belief: Narrative and culture in retirement communities. Ageing and Society, 20, 649-672.

Binsacca, R. 2006. Golden Years: the elder edge of the baby boom generation.... [Online] Available: http://www.allbusiness.com/personal-finance/real-estate/855291-1.html [Accessed 16 February 2010].

Blechman, A. 2008. Leisureville: Adventures in a world without children. New York: Grove Press.

Boseman, C. 2007 The Making of Suburban Heritage: Building "Community", Cultural Significance and Planning Practices. In C. Miller, \& M. Roche, (eds.) Past Matters: Heritage \& Planning History - Case Studies from the Pacific Rim. Newcastle: Cambridge Scholars, 81-103.

Bosman, C. 2012. Gerotopia: Risky Housing for an Ageing Population. Housing, Theory \& Society, 29 (2), 15771.

Bosman, C. 2009. Building a Golden Grove 'community': A study of suburban production processes in South Australia, 1970s-1980s. Planning Perspectives, 24, 219-240.

Bosman, C. 2005. Building 'Community': Sites of Production, Planning Practices \& Technologies of Suburban Government in the Making of the Golden Grove Development, 1984-2003, PhD thesis, School of Natural and Built Environments, University of South Australia.

Bowling, A. 2009. Perceptions of active ageing in Britain: divergences between minority and whole population samples. Age and Ageing, 38, 703-710.

Brodnitzki, T. X. 2007. The Growth of active adult age-restricted retirement communities in Connecticut. Master of Science in Geography unpublished Masters thesis, Central Connecticut State University.

Buchli, V. 2010. Households and 'Home Cultures'. In D. Hicks, \& M. Beaudry, (eds.) The Oxford Handbook of Material Cultural Studies. Oxford: Oxford University Press.

Cheshire, L. A., Rosenblatt, T., Lawrence, G. \& Walters, P. 2009. The Governmentality of Master Planning: Housing Consumption, Aesthetics and Community on a New Estate. Housing Studies, 24, 653-667.

Costley, D. 2006. Master Planned Communities: Do they offer a solution to urban sprawl or a vehicle for seclusion of the more affluent consumers in Australia? Housing, Theory and Society, 23, 157-175.

Fishman, T. C. 2010. Shock of the Gray. New York: Scriber.

Fletcher, R. 2010. Urban Materalities: Meaning, Magnitude, Friction, and Outcomes. In D. Hicks, \& M. Beaudry, (eds.) The Oxford Handbook of Material Cultural Studies. Oxford: Oxford University Press.

Foucault, M. 1997. Technologies of the Self. (Translated by P. Aranov and D. McGrawth). In M. Foucault, (Paul Rabinow ed) Ethics: Subjectivity \& Truth, Essential Works of Foucault 1954-1984, Vol.1. London: Penguin Books, 223-251.

Garnaut, C. 1999. Colonel Light Gardens: Model Garden Suburb. Darlinghurst: Crossing Press.

Gold Coast Publications 2009. A Boom Town for Boomers, goldcoast.com [Online] Available: http://www.goldcoast.com.au/article/2009/04/25/72681 [Accessed on 27 March 2012].

Grant, B. 2007. Retiremnent Villages: More than enclaves for the aged. Activities, Adaptation \& Aging, 31, 3755 .

Grant, B. C. 2006. Retirement Villages: An alternative form of housing on an ageing landscape. Social Policy Journal of New Zealand, 100-113.

Halcyon Communities. [Online] Available: http://www.halcyondays.com.au [Accessed on 27 March 2012]. 
Harding, A. \& Kelly, S. 2007. Baby boomers doing it for themselves. AMP.NATSEM Income and Wealth Reports.

Interview With A Villager (2011 a) January, subscribtion from The Villages Monthly, Florida.

Interview With A VillageR (2011 b) February, subscribtion from The Villages Monthly, Florida.

Interview With A Villager (2011 c) March, subscribtion from The Villages Monthly, Florida.

Isleib, R. A. \& Brady, J. F. 2010. Baby Boomers Guide to Selecting a Retirement Community: 16 Factors you need to consider, jbEmarketing LLC.

Kendig, H. \& Neutze, M. 1999. Housing implications of population ageing in Australia. Policy implications of the ageing of Australia's population, Melbourne, 18-19 March 1998. Productivity Commission and Melbourne Insitiute of Applied Economic and Social Research, 435-450.

Kirk, P. L. 2008. Lifestyle Housing. Urban Land, 76-83.

Knox, P. L. 1992. The Packaged Landscapes of Post-Suburban America. In: J. W. R. Whitehand \& P. J. Larkham, (eds.) Urban landscapes: International Perspectives. London: Routledge.

KPMG 2009. Monash Baby Boomer Study. Property and Demographic Advisory [Online] Available: http://www.kpmg.com/AU/en/IssuesAndInsights/ArticlesPublications/Pages/Monash-Baby-Boomer-Study.aspx.

Magwood, R. n.d. All about baby boomers: Who are they, What they want, How to take care of them, etc... Randall Magwood.

Martin J. T. 1996. Building "Community", Urban Land, 55, 3 28-32; 55-6.

Matusic, M. 2011. How Boomers Could Burst the Bubble, [Online]. Available: http://australianpropertyforum.com/topic/9277164/1/ [Accessed on 27 March 2012].

Mcgovern, S. \& Baltins, E. 2002. The Retirement Village Industry in Australia: Evolution and structure. In R. Stimson, (ed.) The Retirement Village Industry in Australia: Evolution, Prospects, Challenges. Brisbane: Centre for Research into Sustainable Urban and Regional Futures, University of Queensland.

Mchugh K. \& Larson-Keagy E. 2005. These White Walls: The Dialectic of Retirement Communities, Journal of Aging Studies, 19, 241-56.

Minnery, J. \& Bajracharya, B. 1999. Visions, planning processes and outcomes: Master planned communities in south east Queensland. Australian Planner, 36, 33-41.

Murray, S. 2007. The Ageing of Aquarius. Architecture Australia (May/June), 95-8.

Myers, D. \& Ryu, S. 2008. Aging Baby Boomers and the Generational Housing Bubble: Foresight and Mitigation of an Epic Transition. Journal of the American Planning Association, 74, 17-33.

Nevill, J. 2012. Time to Board the Retirement Train?, Property Australia, 22 March 2012, [Online] Available: http://www.propertyoz.com.au/act/Article/NewsDetail.aspx?p=56\&mid=1824. [Accessed on 27 March 2012].

Panelli, R. \& Welch, R. 2005. Why Community? Reading difference and singularity with community. Environment and Planning A, 37, 1589-1611.

Ray White Property News. 2009. Baby Boomers Taking over Gold Coast Real Estate, 20 July 2010. [Online] Available: http://www.raywhite.net/?p=626 [Accessed on 27 March 2012].

Rosenblatt, T., Cheshire, L. \& Lawrence, G. 2009. Social interaction and sense of community in a master planned community. Housing, Theory and Society, 26, 122-142.

Schwarz, N. 2009. Age-segregated communities in the San Francisco Bay Area. Unpublished Masters thesis, Universität Wein.

Seachange Village Arundel. [Online] Available: http://www.seachangegoldcoast.com.au/index.php?page_id=2 [Accessed on 04 April 2012.

Smith, A. E. 2009. Ageing in urban neighbourhoods: Place attraction and social exclusion. Bristol: Policy Press.

Stretton, H. 1989. Ideas For Australian Cities. Sydney: Transit.

Suchman, D. R. 2001. Developing Active Adult Retirement Communities, Washington D.C.: Urban Land Institute. 
The Villages, Florida's Friendliest Hometown. 2012. [Online] Available: http://www.thevillages.com [Accessed on 27 March 2012].

TRACT (S.A.) 1976. Modbury Golden Grove Structure Plan: The future strategies.

UDIA 2012. Qld Housing Recovery Finally Underway, [Online] Available:

http://www.udiaqld.com.au/?pageid=791 [Accessed on 27 March 2012].

Unknown 2009. Halcyon Waters. Urban Developer, 01, 27-31.

Unwin, R. 1994. [1909]. Town Planning in Practice. New York: Princeton Architectural Press.

Waldegrave, C. 2012. Housing tenure and well-being among older citizens. Paper presented at the AHRC, 08-10 February 2012, University of Adelaide.

Walters, P. \& Rosenblatt, T. 2008. Co-operation or Copresence? The comforting ideal of community in a master planned estate. Urban Policy and Research, 26, 397-413.

WHO 2007. Checklist of Essential Features of Age-Friendly Cities. Geneva: WHO.

WHO 2002. Active Ageing: A Policy Framework. Geneva: WHO. 
[Table 1]

\begin{tabular}{|l|l|}
\hline Resident characteristics & Financially secure; healthy and active, aged 50-74; \\
\hline Services/facilities provided & $\begin{array}{l}\text { Extensive: gated security; club house, indoor/outdoor pools; spa; } \\
\text { gymnasium; tennis courts; bowling greens; golf; arts and crafts; } \\
\text { workshop and other activities; cinema; library; BBQ facilities; } \\
\text { communal kitchen; social events coordinator; University of the } \\
\text { Third Age }\end{array}$ \\
\hline Level of care available & Limited \\
\hline House type & Detached suburban with 2-3 bedrooms \\
\hline Development size & Moderate \\
\hline Tenure arrangements & Strata Title, Community Title, Leasehold / Ownership \\
\hline Governance & Private, usually the developer \\
\hline Relationship with financiers & Owner-occupier; no rentals \\
\hline $\begin{array}{l}\text { Level of wider community } \\
\text { involvement }\end{array}$ & Limited as development is largely self contained \\
\hline
\end{tabular}

Source: Adapted from McGovern \& Baltins (2002 p. 36) 'Australian typology of retirement villages', Resort Style. 